\title{
EFFECTS OF MOSQUITO DITCHING IN NORTH CAROLINA
}

\author{
HOWARD L. MARSHALL and FRANK J. SCHWARTZ \\ Institute of Marine Sciences \\ University of North Carolina \\ Morehead City, NC 28557-3209
}

\begin{abstract}
Ditches, creeks, and adjacent estuarine waters of three coastal marshes located at North River and Jarrett Bay, Carteret County, North Carolina were studied between March 1971-March 1972. Irregularly flooded Juncus romerianus (Black Needle Rush) vegetation dominated the marshes. Winds influenced flooding and, during one hurricane, distribution of large vegetation mats on the marshes. Recording tide gauges at North River and Jarrett Bay, referenced to marsh surfaces, documented tidal flooding of the marshes. In a comparison study these recording tide gauges documented flooding of mosquito breeding sites in a manner never previously observed in North Carolina. Ditches produced large quantities of fishes and invertebrates as did creek and estuary habitats. Spot and blue crabs were most abundant and weighed the most at each site. Wind tides and hurricanes influenced flooding, salinities and vegetation fragments that transferred to the estuary. Irregularly flooded marshes, both ditched and unditched, are integral and important components of the estuary.
\end{abstract}

\section{INTRODUCTION}

We usually ignore and consider marsh ditches as sterile habitats. Conversely, do they harbor flora and fauna: do they flood: does ditching alter the ecology of an area and are they useful? These questions are the basis for researches between March 1971 and March 1972 at three Juncus marshes located in Carteret County, North Carolina.

\section{STUDY AREA}

Three Juncus marshes near Beaufort, Carteret County, North Carolina were studied in 1971-1972 (Fig. 1): North River West, a 61 ha marsh, ditched in 1969 for controlling salt marsh mosquitoes, was located on the West shore of North River between Crabbing Creek and North River (Fig. 2). It contained 23 parallel $2.3 \mathrm{~m}$ wide ditches between approximately 450 to $750 \mathrm{~m}$ in length spaced $50 \mathrm{~m}$ apart and 3,370 spoil piles (Fig. 3, Table 1). North River West Juncus marsh was growing on top of the remnants of a pine forest that had been killed by salt water that had accompanied a rising sea level (Marshall 1974). Many pine stumps had been uncovered by the drag lines that dug the ditches in 1968. The ditches and spoil piles occupied $18.5 \%$ of North River West. North River East was an un-ditched marsh, located south of a ditched marsh, on the East side of North River 3,200 m upstream of North River West; a third area was a 70 ha marsh, ditched in 1970 for mosquito control, located between the villages of Williston and Smyrna Creek on the North shore of Jarrett Bay that contained 26 ditches and 2,935 spoil piles (Fig. 3). Ditching and spoil piles occupied $15.3 \%$ of the Jarrett Bay marsh.

\section{METHODS}

All marsh areas and ditch lengths were measured on USDA scale accuracy aerial photographs. Ditch widths, spoils pile sizes, as well as silt depths were measured on a grid pattern at each marsh. Tide gauges (LeopoldStevens Type F) were placed in North River and Jarrett Bay ditches. One hundred twenty nine marsh elevation observations were taken on an established grid on the ditched and un-ditched marsh at North River West by Registered Land Surveyor, Loy Priddy, and referenced to the tide gauge staff, two driven galvanized pipe benchmarks, and a USGS bench mark. A Gurley-Nikon automatic leveler Model BP and an engineering level rod were used for all level measurements. See Kuenzler and Marshall 1973, for more information on the location of the driven benchmarks, the USGS bench mark, the elevation of the bench marks, and the location of permanent heavy concrete markers placed in all studied marshes that perhaps can be recovered to facilitate the exact location of transects, marsh vegetation and marsh elevation stations. The tide gauge at Jarrett Bay, located on Ditch 3, was referenced to a driven galvanized pipe benchmark and to the marsh elevation between the tide gauge and Ditch 2. Visual observations were made to ensure that the entire marsh at Jarrett Bay was flooded simultaneously with the indicated reference point on the tide gauge staff and the tide gauge recorder. Water samples were collected at the surface of each of the 12 seine stations, the two creek stations, and the two estuary stations; water temperatures with mercury thermometers; salinities with a refractometer (Behrens 1965) and oxygen via Winkler titration method (Strickland and Parsons 


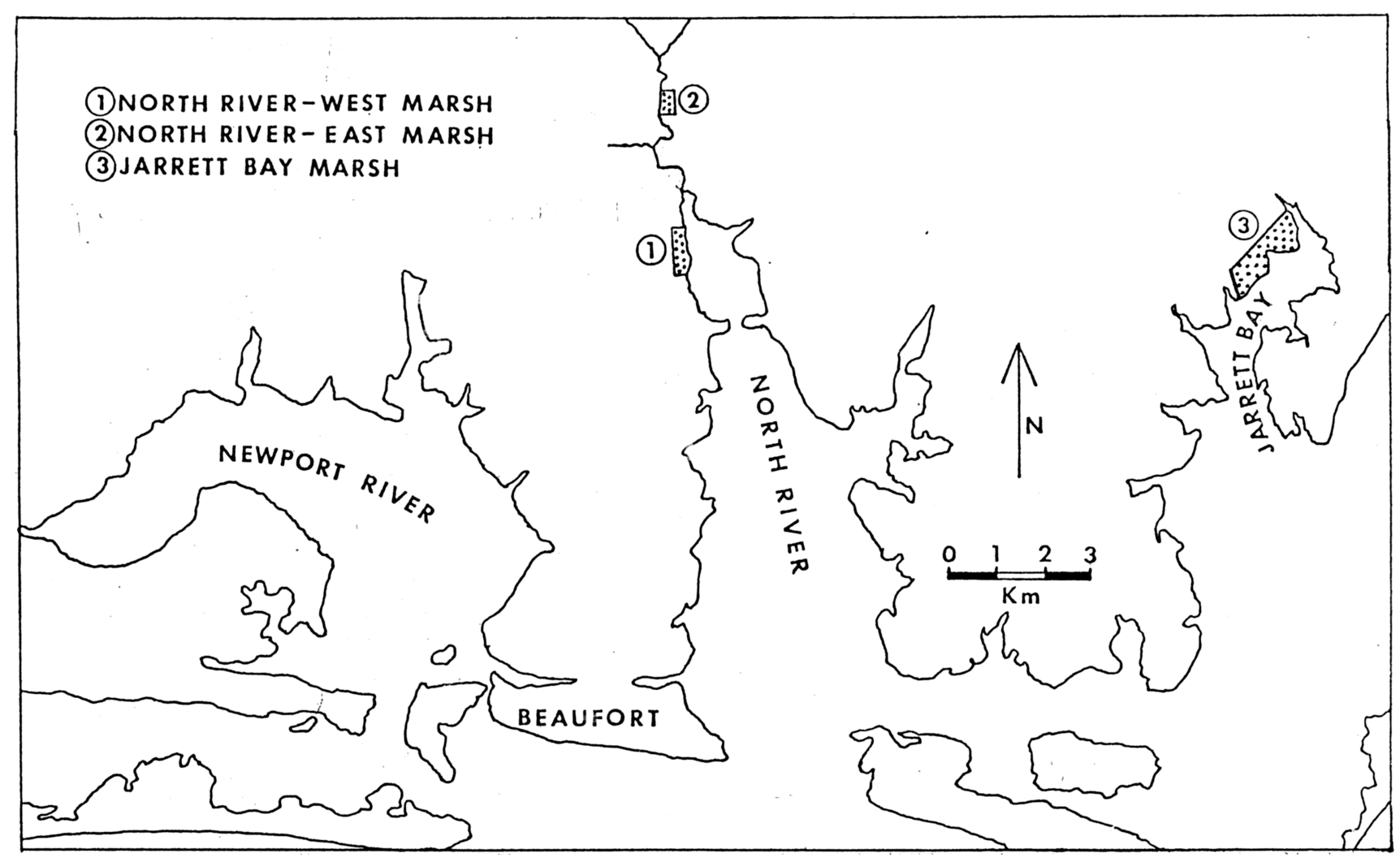

FIG. 1. Marsh study sites in Carteret County, North Carolina, 1971-1972.

1968). Plants (10 species, Table 2) were sampled $1 \mathrm{~m}$ away from numerous transects located on an established grid in all three marshes (217 total vegetation samples). All vegetation within a $0.1 \mathrm{~m}^{2}$ circle was cut within $12 \mathrm{~mm}$ of the marsh surface. All loose vegetation was collected within the circular area; vegetation was identified and sorted in the laboratory as live, dying, and dead (Foster 1968). All plants were dried at $100^{\circ} \mathrm{C}$ to constant weight and weighed to $0.1 \mathrm{~g}$ on a Mettler top loading balance (Table 3).

Blocking nets constructed of $1 \mathrm{~mm}$ plankton mesh netting were $4.9 \mathrm{~m}$ long and $1.8 \mathrm{~m}$ deep, heavily weighted at the bottom, and possessed $200 \mathrm{~mm}$ apart floats at the headline. The seine constructed of Ace netting $(3.0 \times 4.5 \mathrm{~mm}$ opening) was $6.1 \mathrm{~m}$ long with a $1.2 \mathrm{~m}$ bag in the center of the net. The trawl used in 1971 was a flat (2 seam) trawl $5.2 \mathrm{~m}$ wide with a $37 \mathrm{~mm}$ stretch mesh body and a $12 \mathrm{~mm}$ stretch mesh tail bag. The trawl used in 1972 was $4.0 \mathrm{~m}$ wide flat trawl with a $12 \mathrm{~mm}$ stretch mesh body and ACE $(3.0 \times 4.5 \mathrm{~mm}$ opening) tail bag. Repeated samplings of the $30 \mathrm{~m}$ long blocked off ditch stations (Figs. 2, 3) determined that three seinings were necessary for optimum capture of resident fish and invertebrates. The calculated efficiency of three repetitive seinings at the ditch stations varied from $88-97 \%$. The one creek station at North River and the one creek station at Jarrett Bay were also seined three times at each monthly sampling. One $1,000 \mathrm{~m}$ trawl station was established at North River and one at Jarrett Bay. Ditch stations 1, 3, and 5 at north River were sampled March-October 1971 and then terminated due to the extreme difficulty of accessing these stations approximately $500 \mathrm{~m}$ from the North River. Stations 2, 4, and 6 were sampled March 1971-March 1972. Ditch sampling at Jarrett Bay followed the same sampling pattern, with stations 1, 3, and 5 being terminated after October 1971. Each biota station was sampled monthly, usually all the ditch stations at North River were completed in one day and the creek and trawl stations were completed the next day. The stations at Jarrett Bay followed a similar sampling schedule. Captured fishes (47 species, Table 4) and 10 invertebrate species (Table 4) were placed in $10 \%$ formalin, identified, and measured in the laboratory: fish lengths were standard length and shrimp lengths were measured from the tip of the rostrum to the tip of the telson. Weights were determined using a triple beam balance.

A modification of the Shannon-Weaver Formula (Pielou 1969) was used to calculate sample Diversity: $\mathrm{H}^{\prime \prime}=\sum-(\mathrm{N} / \mathrm{N})(\ln \mathrm{N} / \mathrm{N})$, where $\mathrm{N}$ is the number of individuals in the $\mathrm{i}$-th species and $\mathrm{N}$ is the total number of individuals in the sample. The Shannon-Weaver values increase as both the number of species and the equitability of species abundance increase, therefore, it is desirable to calculate these two components separately. The "species richness" component (Margalef 1969) was calculated by: 


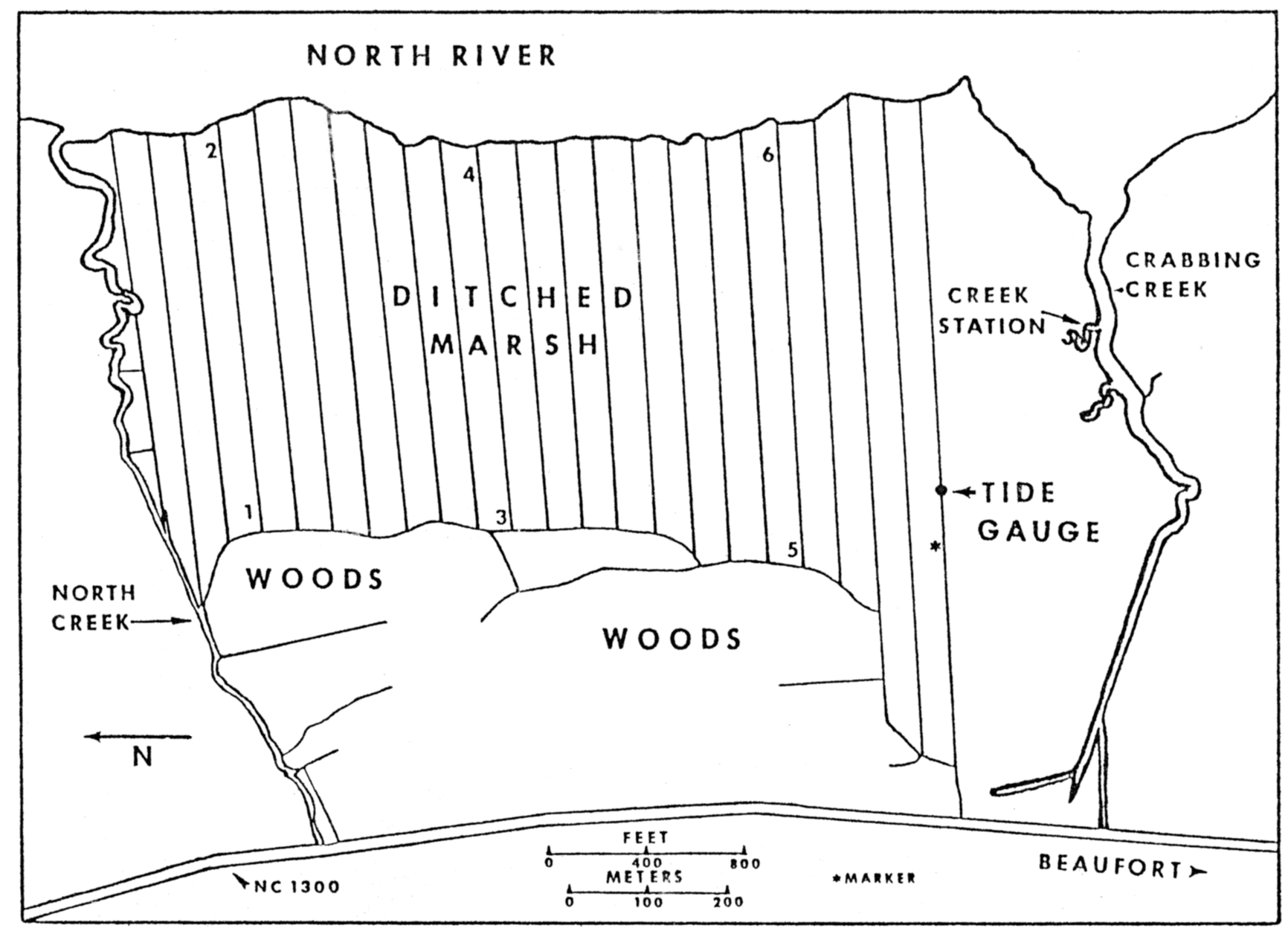

FIG. 2.

$$
\mathrm{D}=(\mathrm{S}-1) / \ln \mathrm{N}
$$

where $\mathrm{S}$ is the number of species and $\mathrm{N}$ is the number of individuals. This formula is more responsive to species number than total number of individuals in the sample. The "evenness" index of Pielou (1969) was used to measure evenness and is calculated by:

$$
\mathrm{J}=\mathrm{H}^{\prime \prime} / \mathrm{H} \max =\mathrm{H}^{\prime \prime} / \ln \mathrm{S}
$$

where $\mathrm{H}^{\prime \prime}$ is the Shannon-Weaver index and $\ln \mathrm{S}$ is the maximum possible value of $\mathrm{H}^{\prime \prime}$. $\mathrm{H}^{\prime \prime}=\mathrm{H} \max$ (when all species are equally abundant).

\section{RESULTS}

Juncus was the dominant plant in North River and Jarrett Bay un-ditched and ditched marshes and on the narrow ditch-side marsh between spoil piles (Table 2). Distichlis spicata was second most abundant (Table 2). Baccharis halimifolia and other marsh species that often grow on slightly higher marsh elevations and/or well drained marsh sites, were growing on many of the spoil piles and on the ditch-side marshes (Table 2). Areas in Section 1 at North River West that had been impacted by heavy equipment travel during ditch construction were also undergoing some limited invasion of Baccharis halimifolia and by the other species found on the spoil piles. LaSalle and Knight (1973) dug holes at measured intervals between ditches at North River West and monitored the distance from the marsh surface to the water for several days after the marsh was flooded. The ditches provided some subsurface drainage at distances up to about 40 feet from the ditches but at farther distances the drainage was minimal. They concluded that large areas between the ditches were not drained enough by the ditches to impede survival of mosquito larvae. Conversely, the areas that were drained sometimes enhanced the survival of mosquito species whose eggs require alternating periods of wet and dry conditions to enhance survival. They found that the studied marshes were flooded so often by rainfall and high tides that marsh ditching had little adverse impact on overall mosquito larvae viability or Juncus marsh vegetation. After extensive marsh sampling (217 samples), analyses 


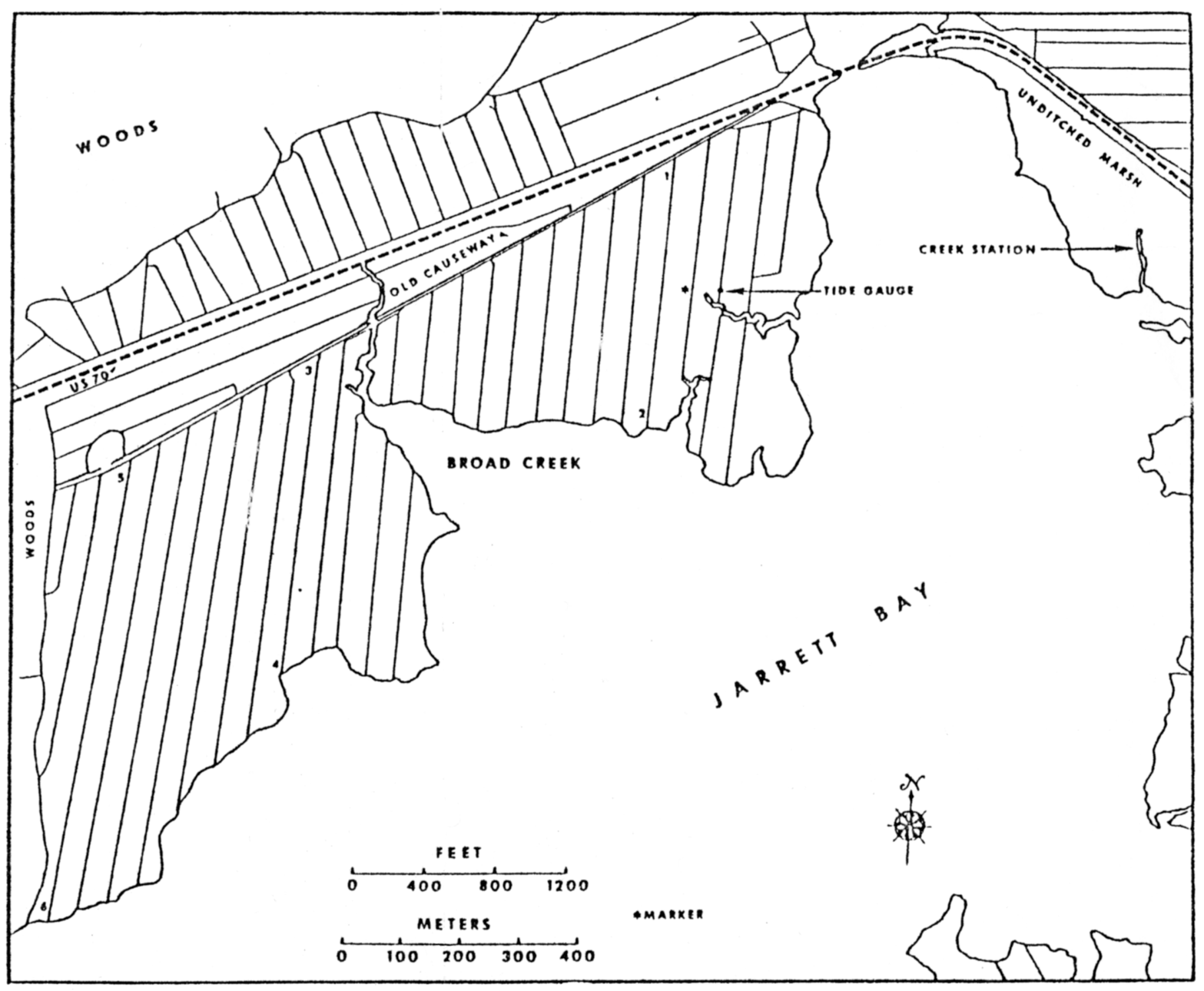

FIG. 3.

of vegetation samples, infrared aerial photography and low level aerial observations, we concluded that except for the presence of the spoil piles and the invasive species beside the ditches, and the invasive species in areas

Table 1. Area of ditched marshes, ditches, creeks, and spoil piles in North River and Jarrett Bay marshes, 1971-1972. (After Kuenzler and Marshall 1973).

\begin{tabular}{lcc}
\hline & North River & $\begin{array}{c}\text { Jarrett Bay } \\
\text { Marsh }\end{array}$ \\
\hline Total area of marsh (incl. creek) & $61.0 \mathrm{ha}$ & $70 \mathrm{ha}$ \\
Total length of ditches & $14,800 \mathrm{~m}$ & $16,070 \mathrm{~m}$ \\
Average width of ditches & $2.3 \mathrm{~m}$ & $2.5 \mathrm{~m}$ \\
Total area of ditches & $3.4 \mathrm{ha}$ & $4.07 \mathrm{ha}$ \\
$\%$ of marsh occupied by ditches & $5.6 \%$ & $5.8 \%$ \\
Area of creek & $0.85 \mathrm{ha}$ & $0.73 \mathrm{ha}$ \\
$\%$ increase of water area & $520 \%$ & $560 \%$ \\
Average depth of ditches & $0.98 \mathrm{~m}$ & $0.74 \mathrm{~m}$ \\
Average area of spoil piles & $25.4 \mathrm{~m} 2$ & $22.6 \mathrm{~m} 2$ \\
Total no. of spoil piles & 3,370 & 2,935 \\
Total area of spoil piles & $7.85 \mathrm{ha}$ & $6.63 \mathrm{ha}$ \\
$\%$ of marsh occupied by spoil piles & $12.9 \%$ & 9.5 \\
$\%$ of marsh in spoil piles and ditches & $18.5 \%$ & $15.3 \%$ \\
\hline
\end{tabular}

Table 2. Plants of irregularly-flooded marshes. Scientific names after Radford, Ahles, and Bell (1964).

\begin{tabular}{ll}
\hline 1. Dominant & \\
Juncus roemerianus Scheele & Needle rush \\
2. Common & \\
Distichlis spicata (L.) Greene & Salt grass \\
Spartina patens (Aiton) Muhl. & Saltmeadow cordgrass \\
3. Others & \\
Pinus taeda L. & Loblolly pine \\
Spartina alterniflora Loisel & Smooth cordgrass \\
Spartina cynosuroides (L.) Roth. & \\
Andropogon virginicus L. & Broom sedge \\
Eleocharis sp. & Spike rush \\
Salicornia sp. & Glasswort \\
Iva frutescens L. & Marsh elder \\
Eupatorium serotinum Michaux & \\
Baccharis halimifolia L. & Groundsel-tree \\
Solidago stricta Aiton & Goldenrod \\
Solidago tenuifolia Pursh. & Goldenrod \\
Borrichia frutscens (L.) DC. & Sea ox-eye \\
\hline
\end{tabular}


Table 3. Standing crop dry weight biomass $(\mathrm{g} / \mathrm{m} 2)$ of marsh plants on un-ditched and ditched marshes. N.R. = North River; J.B. $=$ Jarrett Bay (After Kuenzler and Marshall 1973).

\begin{tabular}{|c|c|c|c|c|c|c|c|}
\hline \multicolumn{8}{|c|}{ Marsh Type } \\
\hline & \multicolumn{2}{|c|}{ Un-ditched } & \multicolumn{3}{|c|}{ Ditched } & \multicolumn{2}{|c|}{ Ditch-side } \\
\hline & N.R.-W & N.R.-E & N.R.-W & N.R.-E & J.B. & N.R.-W & J.B. \\
\hline Number of samples & 20 & 60 & 30 & 30 & 32 & 19 & 16 \\
\hline Dates of sampling & May-July & July-November & May-July & July-November & July-August & May-July & July-August \\
\hline \multicolumn{8}{|l|}{ Biomass } \\
\hline Juncus roemerianus & 1,700 & 1,915 & 1,785 & 1,973 & 1,163 & 895 & 873 \\
\hline Distichlis spicata & 38 & 0.4 & 85 & 0 & 2 & 284 & 39 \\
\hline Eleocharis sp. & 16 & 1.1 & 9 & 0 & 0 & 3 & 0 \\
\hline Salicornia sp. & 0 & 0 & 0 & 0 & 1 & 0 & 1 \\
\hline Borrichia frutescens & 0 & 0 & 0 & 0 & 12 & 16 & 171 \\
\hline
\end{tabular}

impacted by heavy equipment, the ditches at North River and Jarrett Bay did not have a clear and uniform impact on marsh vegetation. New Juncus growth, Juncus was often robust along the edges of the ditches of North River and Jarrett Bay. However, the dirt from many of the spoil piles was eroding in a manner to form levees along the ditches. These levees were impounding water after rainfall or high tides. There were more than $29,600 \mathrm{~m}$ of ditch edge at North River West in the relatively small 70 ha ditched marsh. Sixteen percent of the ditch edge, $4,763 \mathrm{~m}$, had levees that impounded water. The percentage of ditch edge that impounded water was expected to increase as more spoil pile erosion occurred. This impounded water was causing Juncus death in some areas. Juncus death, or any marsh death, can result in permanent water filled depressions. Juncus death could be determined most readily with low- level color infrared $35 \mathrm{~mm}$ aerial photography, coupled with field observations. As the purpose of the ditches was to drain water from the marsh to control mosquito production, the discovery of extensive impounding behind the spoil piles was an important observation. A companion study by North Carolina State University, Department of Entomology, after extensive field study and statistical analysis, found: "Data on both plant cover and on the abundance of mosquito larvae of each species showed such wide variation in both ditched and un-ditched sections that no significant differences between sections could be detected" (LaSalle and Knight 1973). About $600 \mathrm{~m}$ upstream of North River Creek there are remnants of two old causeways that cross the marshes on both sides of the North River. According to local residents, the older causeway was constructed in about 1865 and was used until about 1910 . The other was built in about 1910 and used until 1926, when the present causeway (U.S. 70) was constructed. The causeways were apparently constructed from fill obtained along the roadway and the resulting ditches were about the depth of mosquito control ditches $(1 \mathrm{~m})$ but slightly wider (3$4 \mathrm{~m}$ ). By 1971, ditches along these causeways showed no discernible influence on the Juncus marsh that the causeways crossed. Most of the causeway area was overgrown with Juncus and only an occasional remnant of the "corduroy" log surface protruded above the soil surface. A few Baccharis or Iva bushes were present. The ditches appeared quite stable and Spartina alterniflora along the sloping banks was rare. Marshes with many ditches and eroding spoil piles (as in the marshes studied at North River West) may exhibit different long term ecological changes than did the North River Juncus marsh altered by only two low level causeways. The causeways probably had a short useable life span because fill material excavated from marshes with a large peat content undergoes rapid aerial oxidation when it is piled up so that it is no longer constantly wet and protected by low oxygen conditions. Coal piles undergo a similar phenomenon. Purchased coal exposed to the atmosphere "disappears" at a rate that is substantial and must be accounted for at facilities that burn large quantities of coal. We calculate, based on data from the Beaufort, NC NOAA tide gauge (Zervas 2009), that the relative (local) sea level has risen about 15 inches since the older causeway was constructed in about 1865. A 15 inch rise in sea level should mitigate any adverse impacts that the mosquito ditch program has caused. Unfortunately, a 15 inch rise in sea level will destroy thousands of acres of pine forests and other upland vegetation in coastal North Carolina.

The irregular nature of Juncus marsh flooding was demonstrated by 20 months of tide records obtained at North River West and Jarrett Bay marshes. At North River West, during the period January-August, the marsh is usually flooded less than five times per week and usually less than $8 \%$ of the week. During this period, the marsh may be not flooded by high tides for periods as long as two weeks. During the period September-November, there were usually more than five marsh high tide floods per week and the marsh flooded $30-40 \%$ of the total time. During heavy rains we observed the marsh to be flooded over the entire surface by rainwater up to $150 \mathrm{~mm}$ deep. During the periods of heavy rainfall, tremendous quantities of low salinity water leaves the marshes and fills the ditches and creeks. The Jarrett Bay marsh was farther away 
Table 4. Fishes and invertebrates of ditches, creeks, and tidal marine rivers. Scientific names of fishes after American Fisheries Society, Special Publication No. 6 ( $3^{\text {rd }}$ ed.) 1970.

\begin{tabular}{|c|c|}
\hline Scientific Name & Common Name \\
\hline \multicolumn{2}{|l|}{ Fishes } \\
\hline Elops saurus (Linnaeus 1766) & Ladyfish \\
\hline Anguilla rostrata (Lesueur 1817) & American eel \\
\hline Brevoortia tyrannus (Latrobe 1802) & Atlantic menhaden \\
\hline Anchoa mitchilli (Valenciennes 1878) & Bay anchovy \\
\hline Synodus foetans (Linnaeus 1966) & Inshore lizardfish \\
\hline Opsanus tau (Linnaeus 1766) & Oyster toadfish \\
\hline Urophysics regia (Walbaum 1792) & Spotted hake \\
\hline Cyprinodon variegatus (Lacepede 1803) & Sheepshead minnow \\
\hline Fundulus heteroclitus (Linnaeus 1766) & Mummichog \\
\hline Fundulus luciae (Baird 1855) & Spotfin killifish \\
\hline Fundulus majalis (Walbaum 1792) & Striped killifish \\
\hline Lucania parva (Baird and Girard 1855) & Rainwater killifish \\
\hline Gambusia affinis (Baird and Girard 1853) & Mosquitofish \\
\hline Menidia beryllinia (Cope 1867) & Tidewater silverside \\
\hline Menidia menidia (Linnaeus 1766) & Atlantic silverside \\
\hline Syngnathus fuscus Storer & Northern pipefish \\
\hline Strongylura marina (Walbaum 1792) & Atlantic needlefish \\
\hline Prionotus sp. & Sea robin \\
\hline Pomatomus saltatrix (Linnaeus 1746) & Bluefish \\
\hline Caranx latus (Agassiz 1831) & Horse-eye jack \\
\hline Selene vomer (Linnaeus 1758) & Lookdown \\
\hline Lutjanus analis (Cuvier 1828) & Mutton snapper \\
\hline Lutjanus griseus (Linnaeus 1758) & Gray snapper \\
\hline Eucinostomus argentus Baird and Girard 1855) & Mojarra \\
\hline Eucinostomus gula (Quoy and Grimard 1824) & Mojarra \\
\hline Orthopristis chrys & Pig \\
\hline Archosargus probatocephalus (Walbaum 1792) & Sheepshead \\
\hline Lagodon rhomboides (Linnaeus 1766) & Pinfish \\
\hline Bairdiella chrysura $(\mathrm{Lac}$ & Silver perch \\
\hline Cynoscion nebulosus (Cuvier 1830) & Spotted seatrout \\
\hline Cynoscion regalis (Bloch and Schneider 1801) & Weakfish \\
\hline Leiostomus xanthurus (Lacepede 1802) & Spot \\
\hline Micropogon undulates (Linnaeus 1766) & Croaker \\
\hline Chaetodipterus faber (Broussonet 1782) & Atlantic spadefish \\
\hline Mugil cephalus (Linnaeus 1758) & Striped mullet \\
\hline Mugil curema (Valenciennnes 1836) & White mullet \\
\hline \multicolumn{2}{|l|}{ Ctenogobius bolesoma (Jordan and } \\
\hline & Darte \\
\hline$i$ (Laceped & Naked \\
\hline Gobisoma robustum (Ginsburg 1933) & Code goby \\
\hline \multicolumn{2}{|l|}{ Nicrogobius thallassinus (Jordan and } \\
\hline Gilber 1883) & Green goby \\
\hline Trichiurus lepturus (Linnaeus 1758) & Atlantic cutlassfish \\
\hline Citharichthys macrops (Dresel 1825) & Spotted whiff \\
\hline Citharichthys spilopterus (Gunther 18 & Bay whiff \\
\hline \multicolumn{2}{|l|}{ Paralichthys albigutta (Jordan and } \\
\hline Gilbert 1862) & Gulf flound \\
\hline Paralichthys dentatu: & Summer flounder \\
\hline Paralichthys lethostigma (Jordan and & \\
\hline Gilber 1884) & \\
\hline Symphurus plagiusa (Linnaeus 1766) & Blackcheek tonguefis \\
\hline \multicolumn{2}{|l|}{ Invertebrates } \\
\hline Callinectes sapidus Rathbun & Blue crab \\
\hline Penaeus duorarum Burkenroad & Pink shrimp \\
\hline P. axtecus Ives & Brown shrimp \\
\hline P. setiferus (Linnaeus) & White shrimp \\
\hline Palaemonetes pugio Holthius & Grass shrimp \\
\hline Libinia sp. & Spider crab \\
\hline
\end{tabular}

Table 4. Continued.

\begin{tabular}{ll}
\hline \multicolumn{1}{c}{ Scientific Name } & \multicolumn{1}{c}{ Common Name } \\
\hline Alpheidae & Snapping shrimp \\
Illyanassa obsoleta (Say) & Mud snail \\
Melampus bidentatus Say & Coffee bean snail \\
Geukensia demissus Dillwyn & Ribbed mussel \\
\hline
\end{tabular}

from the tidal inlets and was more subject to wind tides. It was flooded more often than the North River West Marsh. It was flooded on average about 5-10 times per week during January-August and 8-15 times per week during September through November. North and northeast winds prevailed during SeptemberNovember, as is typical for that time of the year (U.S. Naval Weather Service Command, 1973). At times, the low tide did not go low enough to leave the marsh surface at Jarrett Bay and the water covering the marsh became an extension of the estuary for days on end. The drag line operators that excavated these ditches stated said that in the fall when they were digging, the water once continuously flooded the Jarrett Bay marsh to a depth exceeding 18 inches for a period of more than three weeks. The sea level of many North Carolina sounds and bays are strongly influenced the by velocity, duration, and direction of the wind (Roelofs and Bumpus 1953).

A review of the literature through 2013 indicates that this 1971-1972 study was perhaps the best documentation of marsh inundation by use of precision tide gauges and level surveys ever accomplished in North Carolina and perhaps the entire East Coast of the United States.

\section{Effects of Hurricanes on Juncus Standing Crop}

Some dead Juncus may be exported to the estuary when marshes are inundated by high storm tides (Waits 1967). Two storms in 1971 provided rare opportunities to measure the impacts of storms on Juncus standing crop. Tropical storm Doria made landfall near Morehead City 27 August 1971 with winds of about $65 \mathrm{mph}$. The average loss of Juncus at all stations was $266 \mathrm{~g} / \mathrm{m} 2$, about one-third of the annual productivity of Juncus (Williams and Murdoch 1972). Hurricane Ginger made landfall near Morehead City 30 September 1971 with winds of about $75 \mathrm{mph}$. There were no significant changes in the standing crop of Juncus after Ginger and the extensive flooding caused by the wind tides of September-November 1971. The earlier storm, Doria, may have already removed much of the vegetation that could be removed by a minimal hurricane. Kuenzler and Marshall (1973) collected a limited amount of data on phosphorus exchange between the ditches and the ditched marsh at Jarrett Bay. They found that the 
Juncus marsh retained more than $30 \%$ of the particulate phosphorus pumped onto a Juncus marsh and approximately $42 \%$ of the particulate phosphorus that entered the marsh during a high tide. Juncus marshes have a high stem density and are very resilient. They offer considerable resistance to the movement of larger vegetation fragments and probably few of the larger fragments are exported from the marsh except during major storms. The dense tough stems also offer considerable resistance to walking through the marsh. During many trips though the marsh we noted very little reptile, bird, or mammal life in the middle of the vast Juncus marshes. However, there was an abundance of small "crab holes" that supported a rich population of small fish, invertebrates, and insects (LaSalle and Knight 1973). They observed that the water level in the crab holes were usually little affected by marsh ditching and provided extensive habitat for mosquito larvae.

Water temperatures varied $0-30^{\circ} \mathrm{C}$ in North River and $10-34^{\circ} \mathrm{C}$ in Jarrett Bay, lowest in January and February and highest in June and July. Salinities varied 0-26 ppm in North River, 10-30 ppm in Jarrett Bay. Oxygen was often low in the ditches in the late summer, especially at North River. However, by the time that the low oxygen became prevalent most of the juvenile fish and invertebrates had grown up and exited the ditches.

\section{Fishes and Invertebrates}

Forty-five species of fishes (Table 4) were collected between March 1971 and March 1972. Fish numbers were highest in North River ditches at 12,297 fishes at six stations and lowest in Jarrett Bay ditches at 9,832 at six stations. The creek in North River harbored 3,267 at one station while the Jarrett Bay creek harbored 4,271 at one station. The North River estuary contained 1,839 fishes at one station while Jarrett Bay estuary contained 1,209 fishes at one station.

Invertebrates inhabiting North River ditches were 7,070 at six stations, while in Jarrett Bay ditches there were 4,055 at six stations. The North River creek harbored 3,827 invertebrates at one station while Jarrett Bay had 2,590 invertebrates at one station. The North River estuary possessed 2,145 invertebrates at one station, while Jarrett Bay estuary possessed 169 invertebrates at one station. Weight data for all fish and invertebrate species, in all samples, can be found in Kuenzler and Marshall 1973. A total of 17,403 fishes were captured at North River stations and 15,393 at Jarrett Bay stations. A total of 32,796 fishes were captured at all stations, A total of 13,042 invertebrates were captured at the North River stations and 6,814 at Jarrett Bay. The total invertebrates for North River and Jarrett Bay were 19,856.
Total Fishes and Invertebrates for all Ditches at North River and Jarrett Bay

We used the total lengths of all the ditches at both ditched marshes (Table 1) and the length of the ditch stations, $30 \mathrm{~m}$, and the data from March 1971 (ditches) to estimate the total number of fishes and invertebrates at North River West and Jarrett Bay ditched marshes. The total number of fishes in North River ditches was 359,800. The total number of fishes in Jarrett Bay was 198,997. The total number of fishes in North River and Jarrett Bay was 558,798 . The total number of invertebrates in North River ditches was 122,183. The total number of invertebrates in Jarrett Bay was 29,016. The total number of invertebrates for North River and Jarrett Bay was 151,199. The total number of fishes and invertebrates in both North River and Jarrett Bay was 709,997. The fish and invertebrate species enter and leave the ditches over a several month period when the ditches appear to provide good habitat and protection from large predators, therefore the studied ditched marshes may provide habitat for several million individuals during one year.

Spot, muller menhaden, and Bay anchovy were most abundant in North River ditches, while Spot, menhaden, mummichog, and silversides were most abundant in Jarrett Bay ditches. Grass shrimp, brown shrimp, mysids, and blue crab were the most abundant in the North River ditches and grass shrimp, blue crab, brown shrimp, and pink shrimp were most abundant in Jarrett Bay ditches.

Species abundance and biomass trends during the study suggest the mosquito ditches served as suitable habitat for small specimens, and may have provided protection and enhanced survival. For most species, the number of fishes and invertebrates was highest in March 1971 and decreased to a low in November. For the most abundant species, frequency distribution of standard length increased from the early spring to late summer. A good example is Spot, which increased from a maximum size in the $20 \mathrm{~mm}$ range in March to over $60 \mathrm{~mm}$ in August Figure 4.

\section{Fish Indices North River}

The calculated Shannon-Weaver $\left(\mathrm{H}^{\prime}\right)$, Margalef (D), and Pielou $(\mathrm{J})$ diversity indices for fishes revealed that mean $\mathrm{H}^{\prime \prime}$ and $\mathbf{J}$ diversity was lowest in the ditches and highest in the estuary and that this relationship was similar for data collected for the period of March 1971October 1971 and for the period March 1971-March 1972 (Table 13). The average D index was slightly higher in the ditches than in the creeks, but the highest $\mathrm{D}$ index was in the estuary.

\section{Fish Indices Jarrett Bay}

The Shannon-Weaver Index $\left(\mathrm{H}^{\prime \prime}\right)$ and the Pielou Index $(\mathrm{J})$ were higher for the fishes in the creek during 


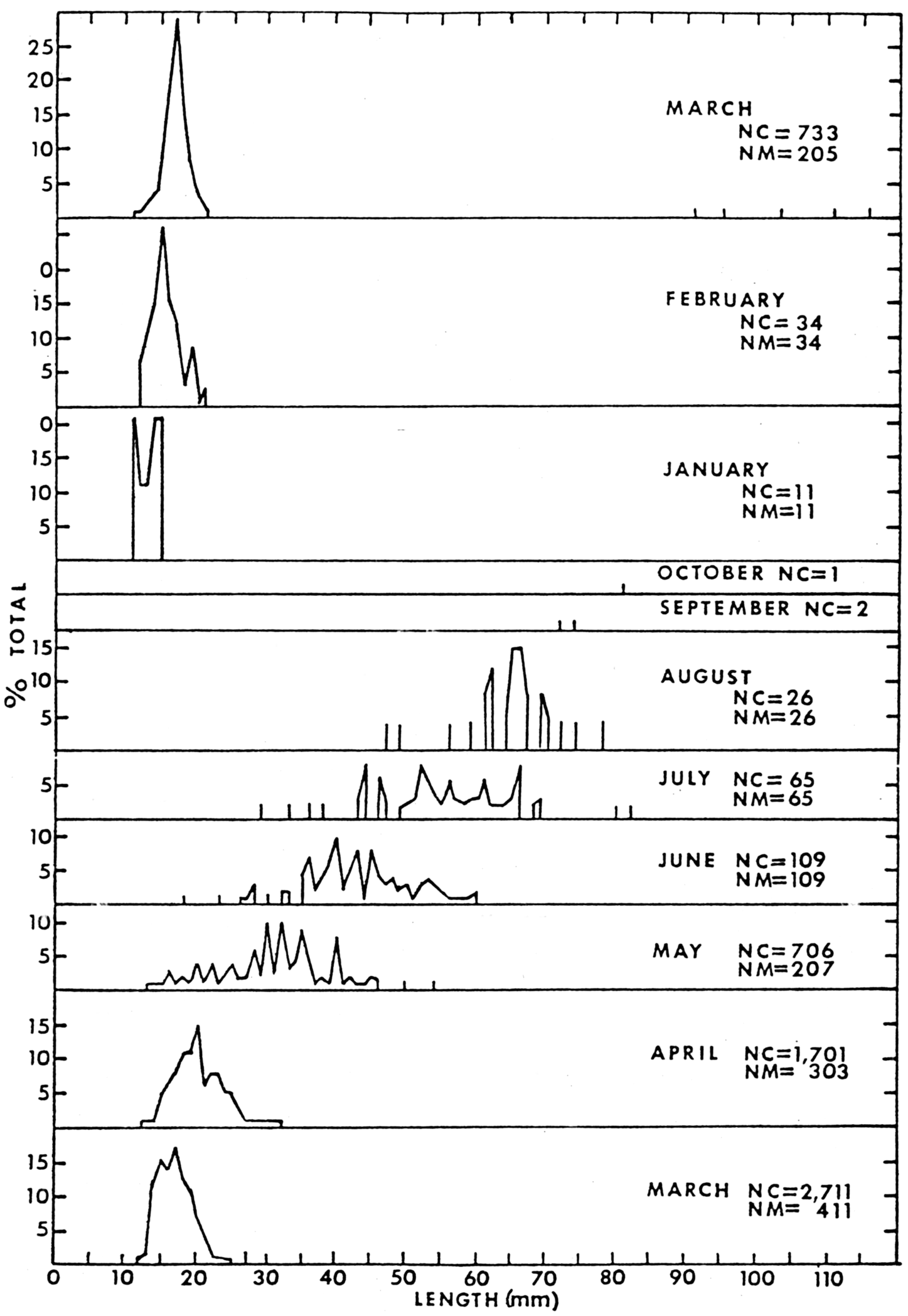

FIG. 4. Frequency distribution of standard length of spot in the North River ditches during March 1971-March 1972. NC = Number caught. $\mathrm{NM}=$ Number measured. 
Table 5. Numbers of fish (A) and invertebrates (B) inhabiting ditches, creeks and estuaries at North River and Jarrett Bay March 1971-March 1972.

\begin{tabular}{lcc}
\hline & North River & Jarrett Bay \\
\hline A) Ditches 1-6 & 12,297 & 9,832 \\
Creeks & 3,267 & 4,271 \\
Estuaries & 1,839 & 1,240 \\
Total & 17,403 & 15,393 \\
B) Ditches 1-6 & 7,070 & 4,055 \\
Creeks & 3,827 & 2,590 \\
Estuaries & 2,145 & 169 \\
Total & 13,042 & 6,814 \\
\hline
\end{tabular}

March 1971-October 1971 than in the ditches or estuary (Table 5), and the Margalef diversity (P) was highest in the Jarrett Bay ditches. Generally, these indices changed very little as a result of five additional months of sampling; however, in the estuary the D Index did increase enough as a result of catching three additional species so that $\mathrm{D}$ was then higher in the estuary than in the other sampled habitats. There were only 15 fish species in the creek; yet they were so evenly distributed that the J Index was higher in the creek (Table 5). Fish indices are valuable tools overall but for a system that has low dissolved oxygen in late summer and perhaps low indices, the diversity indices concept has limited value for predicting the overall value of the system as fishery nursery habitat.

\section{DISCUSSION}

Species Diversity of Fishes and Invertebrates at North River and Jarrett Bay

After comprehensive analysis of fish populations in North River and Jarrett Bay we found that the overall condition of the fish and invertebrate populations was healthy. Diversity indices at North River and Jarrett Bay compared favorably with diversity indices in numerous studied aquatic environments: Dahlburg and Odum (1970), Olinger et al. (1975), Copeland, Birkhead, and Hobson (1974), Hester and Copeland (1975), Subrahmanyam and Drake (1975), Homer (1975), McErlean, O'Connor, Mihursky, and Gibson (1973), Austin (1976). Marshall (1976) provides detailed analyses of the diversity indices at North River West and Jarrett Bay.

\section{Comparisons With Other Quantitative Studies} (Fishes and Invertebrates)

There are a number of recent studies that provide quantitative data on fish and invertebrate populations in ditches, creeks, and estuaries. Tonjes (2013) reviewed extensive literature on mosquito ditches along the Atlantic coast of the U.S. and found that recent innovations for mosquito control, termed open marsh water management (OMWM), have been used from Virginia to Maine and sometimes offered benefits for mosquito control and could offer benefits for fishes, invertebrates, birds and other wild life. Kilgen, Harris, and Kraemer (1973) used rotenone and seines as aides to determine the standing crop of natural fish populations in brackish-water oil field pipeline canals in coastal Louisiana. These canals were constructed so that the canals were isolated from the estuary except during very high tides, therefore, block nets were unnecessary. Turner and Johnson (1972) used block nets to isolate five tidal streams near Port Royal Sound, South Carolina (Turner and Johnson 1974) and then used rotenone and seines to capture the fishes and invertebrates. Turner and Johnson (1973) used a haul seine to obtain a semi-quantitative sample of fish populations along the shoreline of Newport River, North Carolina. Adams (1974) used a portable drop net to obtain a quantitative sample of fish populations in eelgrass beds in Newport River and Bogue Sound, North Carolina. Homer (1975) used block nets to trap fishes in tidal creeks draining Juncus marshes near Crystal River, Florida. Kjelson, Johnson, Garner, and Bell (1974), working at Beaufort, North Carolina, blocked the entrance to a Spartina fringed pond and repeatedly seined the area during low tide to determine the standing crop of fishes and invertebrates.

Fish biomass in the pipeline canals in Louisiana was high (Kilgen et al. 1973); the authors attributed this high biomass to the entrapment of fishes in the canals. Turner and Johnson, while sampling tidal creeks near Port Royal Sound (1972) and Charleston, South Carolina (1974), found the highest areal densities for fishes and invertebrates reported for estuarine areas. The biomass was higher than in three of the four pipeline canals in Louisiana. The tidal amplitudes in South Carolina are large and the fish probably spread far out into the marsh during high tide, however, the area of marsh inundated during high tide, was not calculated. Kjelson and Johnson's data (1973), from a blocked-off pond are based on the $8,500 \mathrm{~m}^{2}$ surface area of the pond at low tide. If the $18,000 \mathrm{~m}^{2}$ of substrate covered by every high tide had been used as a basis, the standing crops estimates would be reduced by a factor of 2.1. The data we obtained were based on the creek and ditch dimensions and did not consider the 75-100-fold increase in water surface area available when the marshes were flooded. Turner and Johnson (1973) found a relatively low biomass along the shoreline of Newport River, North Carolina; however, they were working in an open system and did not use any type of block net. Adams (1974) found relatively fewer fishes in the Newport River and Bogue Sound eelgrass beds; however, the sampling efficiency of drop nets is lower 
than that of the block net and repetitive seining methods utilized in this study (Kjelson and Johnson 1973).

The number of organisms $/ \mathrm{m}^{2}$ in the North River creek was greater than for any of the other studies except for the tidal creeks near Charleston, South Carolina (Turner and Johnson 1974). The high numerical density probably reflects the excellent habitat of the narrow, shallow, Spartina fringed creek. The Jarrett Bay creek had a relatively large number of organisms $/ \mathrm{m}^{2}$; yet, the biomass was lower than in any of the other studied ditches and creeks.

The areal biomass in the ditches and creeks was comparatively low and the average weight per organism was small (0.9 g/organism). Based on the high numerical density and the low mean weight of these animals, the studied ditches and creeks are some of the richest habitats for small estuarine animals ever reported. Only the small creeks near Charleston, South Carolina, have more animals per unit area and a smaller mean weight per animal. Undoubtedly, many other habitats are just as good, but sampling in open systems with large mesh nets has not yielded adequate data to resolve the picture. The trawl data obtained in the studied estuaries indicate a relatively meager faunal population in the open water habitat. Small trawls are quite selective (Kjelson, Johnson, Garner, and Watson 1973) and the trawl data probably severely underestimate the fish and invertebrate populations in the open water. Trawls for demersal and semidemersal fishes and invertebrates should be as large as practicable and should be pulled quite rapidly. Trawls with large mesh openings catch mostly the larger fauna; fine mesh trawls $(3.0 \times 4.5 \mathrm{~mm})$ such as used in this study for the 1972 trawl samples are excellent for the small fishes and invertebrates but are difficult to pull fast enough to catch the larger fishes. Roessler (1965) did an analysis of the variability of fish populations taken by otter trawl in Biscayne Bay and found that seven to eight replicates are needed to detect a difference of five species and 10 replicates are needed to detect a $10 \%$ change in the number of individuals with $95 \%$ confidence.

Determination of the abundance of certain types of fishes and invertebrates inhabiting the Juncus marsh vegetation was not the purpose of this study; however, we observed that the marshes at Jarrett Bay were utilized by tremendous schools of Fundulus heteroclitus during the fall floodings. Las Salle (pers. comm.) using a large pipette, extracted numbers of $40-60 \mathrm{~mm}$ (standard length) $F$. heteroclitus inhabiting crab holes in Juncus marshes at North River West during low tide when all surface water had drained off the marsh. LaSalle and Knight (1973) observed numbers of mosquito larvae in these same holes. Harrington and Harrington (1961) described the food habits of juvenile fishes invading an irregularly flooded salt marsh in Florida. Tabb, Drummond, and Kenny (1974) observed that small fish utilize Juncus and other irregularly flooded salt marsh in the everglades National Park, Florida and speculated on the role that mosquitoes may play in the transfer of energy from the marsh vegetation to other estuarine food chains. Subrahmanyam, Kruczynski, and Drake (1976) observed 18 species of benthic invertebrates in Juncus marshes in North Florida. Invertebrate density in those marshes was $540 / \mathrm{m}^{2}$ and $381 / \mathrm{m}^{2}$ at lower and higher elevations, respectively.

Odum and de la Cruz (1967) provided the classic description of the export of detritus from regularly flooded Spartina alterniflora marshes and the subsequent utilization of this detritus by marine organisms. De la Cruz (1973) was of the opinion that Juncus marshes in Mississippi export detritus much like the Spartina marshes in Georgia, however his work in Mississippi failed to include the basic transport studies that were essential to his previous work. He relied upon the observation of a decrease in dead Juncus standing crop from winter to summer and a corresponding increase in detritus concentrations within the Mississippi estuary. Proof that the two events are correlated is dependent upon the transport studies.

Although mosquito control ditches provide a large expansion of aquatic habitat and the ditches are utilized by quantities of fishes and invertebrates, it is difficult to predict what effect this additional habitat has on animal populations in the open waters of the estuary. Thousands of kilometers of ditches have been dug in the coastal marshes of North Carolina, but no dramatic shifts in species or numbers have been observed that can be attributed to the presence of the ditches. Natural fluctuations in fish and invertebrate populations are so extreme that the effect of an additional variable such as the ditches can rarely be identified. The ditches, because of their vertical sides and lack of emergent vegetation, are not a type of habitat identical to the natural creeks, and ditches develop a different species composition than creeks. Poor circulation within the ditches may contribute to this difference. During a rising tide that does not inundate the marsh, only enough water enters a ditch to fill it to the high water mark. The resulting sluggish currents do not carry much food or oxygen; however, when a tide inundates the marsh large volumes of water flow through the ditches, producing rapid currents. The decreasing cross section toward the headwaters of a creek and the increasing cross section with elevation insures good circulation and flushing.

Although the ditches were attractive to a different species composition of fishes and invertebrates than the studied creeks or estuaries, the Shannon-Weaver diversity indexes $\mathrm{H}^{\prime \prime}$ did not differ appreciably among the sampled habitats (Tables 6-9). This indicates that the total environmental stresses within the ditches were not different from those in creeks and estuaries until the low oxygen conditions of late summer. 
Table 6. Shannon-Weaver $\left(\mathrm{H}^{\prime \prime}\right)$, Margalef (D), and Pielou (J) diversity indices for fishes at the North River ditch, creek, and estuary stations for March-October 1971 (A) and March 1971-March 1972 (B).

\begin{tabular}{|c|c|c|c|c|c|}
\hline \multicolumn{6}{|c|}{ A. March-October 1971} \\
\hline \multirow[b]{2}{*}{ Station } & \multicolumn{2}{|c|}{ Total } & \multirow[b]{2}{*}{$\mathrm{H}^{\prime \prime}$} & \multirow[b]{2}{*}{ D } & \multirow[b]{2}{*}{$\mathrm{J}$} \\
\hline & Species & Individuals & & & \\
\hline \multicolumn{6}{|l|}{ Ditch } \\
\hline 1 & 16 & 2,431 & 1.21 & 1.92 & 0.44 \\
\hline 3 & 16 & 1,385 & 1.41 & 2.07 & 0.51 \\
\hline 5 & 16 & 1,816 & 1.16 & 2.00 & 0.42 \\
\hline$X(1,3,5)$ & 16 & 1,877 & 1.26 & 2.00 & 0.46 \\
\hline 2 & 17 & 1,495 & 1.70 & 2.19 & 0.60 \\
\hline 4 & 16 & 2,111 & 0.82 & 1.96 & 0.30 \\
\hline 6 & 22 & 1,494 & 1.68 & 2.87 & 0.54 \\
\hline$X(2,4,6)$ & 18.3 & 1,700 & 1.40 & 2.34 & 0.48 \\
\hline$X(1-6)$ & 17.2 & 1,789 & 1.33 & 2.17 & 0.47 \\
\hline Creek & 16 & 1,387 & 1.48 & 2.07 & 0.53 \\
\hline Estuary & 23 & 1,237 & 1.78 & 3.09 & 0.57 \\
\hline \multicolumn{6}{|c|}{ B. March 1971-March1972 } \\
\hline & \multicolumn{2}{|c|}{ Total } & & & \\
\hline Station & Species & No. Fishes & $\mathrm{H}^{\prime \prime}$ & $\mathrm{D}$ & $\mathrm{J}$ \\
\hline 2 & 18 & 1,667 & 1.65 & 2.29 & 0.57 \\
\hline 4 & 16 & 3,052 & 0.87 & 1.87 & 0.31 \\
\hline 6 & 22 & 1,946 & 1.70 & 2.77 & 0.55 \\
\hline$X(2,4,6)$ & 18.7 & 2,222 & 1.41 & 2.31 & 0.48 \\
\hline Creek & 17 & 3,269 & 1.55 & 1.98 & 0.55 \\
\hline Estuary & 23 & 1,839 & 1.96 & 2.93 & 0.63 \\
\hline
\end{tabular}

Ditches appear to be good habitat for certain fish species, suggesting that fish have adapted over time to use these areas when dissolved oxygen is optimal. Data from the study indicate a sequential arrival of species that may minimize competition for habitat.

Any positive benefits of the additional aquatic habitat provided by ditching are probably offset by the adverse effect of more rapid salinity variations in the estuary as a result of the rapid draining of rainfall runoff from the marshes and uplands. With increased development along the marshes and an increase in the use of septic tanks, many of the ditches will become conduits for the rapid transfer of additional fresh water, bacteria, viruses, dissolved nutrients, dissolved carbon, oils, heavy metals, and pesticides and other toxics to the adjacent estuaries. The increased pollution in the estuaries will also result in additional shellfish areas being closed. The effect on fish and shellfish populations will depend on the degree of eutrophication and contamination.

Ditches and spoil piles occupy $18.5 \%$ of the North River West ditched marsh and $15.3 \%$ of the Jarrett Bay ditched marsh; however, these alterations did not have a well-defined effect on Juncus standing crop except that dying and dead Juncus was usually considerably reduced along the edges of ditches. Although ditches provide some subsurface drainage at distances up to $20 \mathrm{~m}$ from
Table 7. Shannon-Weaver $\left(\mathrm{H}^{\prime \prime}\right)$, Margalef (D), and Pielou (J) diversity indices for invertebrates at the North River ditch, creek, and estuary stations for March-October 1971 (A) and March 1971March 1972 (B).

\begin{tabular}{|c|c|c|c|c|c|}
\hline \multicolumn{6}{|c|}{ A. March-October 1971} \\
\hline \multirow[b]{2}{*}{ Station } & \multicolumn{2}{|c|}{ Total } & \multirow[b]{2}{*}{$\mathrm{H}^{\prime \prime}$} & \multirow[b]{2}{*}{$\mathrm{D}$} & \multirow[b]{2}{*}{$\mathrm{J}$} \\
\hline & Species & Individuals & & & \\
\hline \multicolumn{6}{|l|}{ Ditch } \\
\hline 1 & 5 & 380 & 0.86 & 0.67 & 0.54 \\
\hline 3 & 7 & 650 & 1.13 & 0.93 & 0.58 \\
\hline 5 & 3 & 182 & 0.91 & 0.38 & 0.83 \\
\hline$X(1,3,5)$ & 5 & 404 & 0.97 & 0.66 & 0.65 \\
\hline 2 & 5 & 1,173 & 1.21 & 0.57 & 0.75 \\
\hline 4 & 5 & 1,917 & 0.50 & 0.53 & 0.31 \\
\hline 6 & 6 & 1,580 & 1.32 & 0.68 & 0.74 \\
\hline$X(2,4,6)$ & 5.3 & 1,557 & 1.01 & 0.59 & 0.60 \\
\hline$X(1-6)$ & 5.2 & 980 & 0.99 & 0.63 & 0.63 \\
\hline Creek & 4 & 2,695 & 0.22 & 0.38 & 0.16 \\
\hline Estuary & 7 & 1,298 & 0.62 & 0.84 & 0.32 \\
\hline \multicolumn{6}{|c|}{ B. March 1971-March1972 } \\
\hline & \multicolumn{2}{|c|}{ Total } & & & \\
\hline Station & Species & No. Fishes & $\mathrm{H}^{\prime \prime}$ & $\mathrm{D}$ & $\mathrm{J}$ \\
\hline 2 & 6 & 1,474 & 1.48 & 0.69 & 0.83 \\
\hline 4 & 6 & 2,086 & 0.62 & 0.65 & 0.35 \\
\hline 6 & 7 & 2,298 & 1.56 & 0.78 & 0.80 \\
\hline$X(2,4,6)$ & 6.3 & 1,953 & 1.22 & 0.71 & 0.66 \\
\hline Creek & 5 & 3,827 & 0.66 & 0.49 & 0.41 \\
\hline Estuary & 8 & 2,145 & 1.37 & 0.91 & 0.66 \\
\hline
\end{tabular}

the ditch (La Salle and Knight 1973) the entire marsh is inundated by tides $9.3 \%$ of the total time at North River and $28 \%$ of the total time at Jarrett Bay, and Juncus standing crop is not appreciably affected. In addition, levees formed by ditching tend to retain some rainfall and tidewater upon the marshes. If the relative sea level continues to rise at the rate, $2.57 \mathrm{~mm} / \mathrm{yr}$, observed at the NOAA Beaufort, NC tide gauge for the period 19532006 (Zervas 2009) the marsh drainage provided by these ditches will become less effective and should have less effect upon the ditched marshes. Sea level at the two sites has risen approximately $111.0 \mathrm{~mm}$ (4.4 in) since the project was initiated in March 1971. Dredging of the Beaufort Inlet, the Morehead City ship channel, and other inlet changes have increased the tidal range in the area and relative sea level may have risen more than $111 \mathrm{~mm}$ at the study sites (Zervas 2004) (North Carolina Coastal Resource Commission 2010).

\section{Need for Further Research}

The present study documented the standing crop of fishes and invertebrates within ditches and creeks, however relatively little information was obtained regarding the types and abundance of fishes and invertebrates that occupy the marsh vegetation when high tides innundated 
Table 8. Shannon-Weaver $\left(\mathrm{H}^{\prime \prime}\right)$, Margalef (D), and Pielou (J) diversity indices for fishes at the Jarrett Bay ditch, creek, and estuary station for March-October 1971 (A) and March 1971-March 1972 (B).

\begin{tabular}{|c|c|c|c|c|c|}
\hline \multicolumn{6}{|c|}{ A. March-October 1971} \\
\hline \multirow[b]{2}{*}{ Station } & \multicolumn{2}{|c|}{ Total } & \multirow[b]{2}{*}{$\mathrm{H}^{\prime \prime}$} & \multirow[b]{2}{*}{ D } & \multirow[b]{2}{*}{$\mathrm{J}$} \\
\hline & Species & Individuals & & & \\
\hline \multicolumn{6}{|l|}{ Ditch } \\
\hline 1 & 15 & 618 & 1.87 & 2.18 & 0.69 \\
\hline 3 & 15 & 1,220 & 1.58 & 1.97 & 0.58 \\
\hline 5 & 14 & 1,033 & 1.46 & 1.87 & 0.55 \\
\hline$X(1,3,5)$ & 14.7 & 957 & 1.64 & 2.01 & 0.61 \\
\hline 2 & 14 & 2,636 & 1.24 & 1.65 & 0.47 \\
\hline 4 & 16 & 1,508 & 1.64 & 2.05 & 0.59 \\
\hline 6 & 18 & 1,672 & 1.38 & 2.29 & 0.48 \\
\hline$X(2,4,6)$ & 16.0 & 1,939 & 1.42 & 2.00 & 0.51 \\
\hline$X(1-6)$ & 15.3 & 1,448 & 1.52 & 2.00 & 0.56 \\
\hline Creek & 13 & 2,122 & 1.60 & 1.57 & 0.62 \\
\hline Estuary & 14 & 1,205 & 1.13 & 1.83 & 0.43 \\
\hline \multicolumn{6}{|c|}{ B. March 1971-March1972 } \\
\hline & \multicolumn{2}{|c|}{ Total } & & & \\
\hline Station & Species & No. Fishes & $\mathrm{H}^{\prime \prime}$ & $\mathrm{D}$ & $\mathrm{J}$ \\
\hline 2 & 16 & 2,907 & 1.28 & 1.88 & 0.46 \\
\hline 4 & 16 & 1,667 & 1.71 & 2.02 & 0.62 \\
\hline 6 & 20 & 2,387 & 1.32 & 2.44 & 0.44 \\
\hline$X(2,4,6)$ & 17.3 & 2,320 & 1.44 & 2.11 & 0.51 \\
\hline Creek & 15 & 4,271 & 1.47 & 1.68 & 0.54 \\
\hline Estuary & 17 & 1,290 & 1.18 & 2.23 & 0.42 \\
\hline
\end{tabular}

the marsh or what lives in the numerous crab holes in the areas between the ditches and the unditched marsh and the extensive Juncus marshes that remain un-ditched. There is little information available regarding the impacts that these animals may have on energy and nutrient exchanges between the marsh region and the estuary. Similarly there was no information obtained regarding nitrogen flux between Juncus marshes and the estuary or between Juncus marshes and the atmosphere. Information regarding dissolved and particulate carbon flux between Juncus and the estuary would also be helpful in understanding the role of Juncus marshes in estuarine productivity.

Natural marsh pools are not a prominent feature of Juncus marshes in North Carolina and it was not apparent that ditching had a significant impact on the number of pools in Juncus marshes. However, pools are/ were a significant factor in marshes from New Jersey to Maine (Adamowicz and Roman 2005). Pools could be constructed in some of the extensive Juncus marshes in North Carolina, if the work could be accomplished without degrading the marshes by placement of fill material. Such pools would provide good habitat for ducks, geese and other aquatic birds. They could also perhaps be used to control indentified pockets of serious mosquito breeding areas. They would not pose as many management problems as the permanent impoundments
Table 9. Shannon-Weaver $\left(\mathrm{H}^{\prime \prime}\right)$, Margalef (D), and Pielou (J) diversity indices for fishes at the Jarrett Bay ditch, creek, and estuary station for March-October 1971 (A) and March 1971-March 1972 (B).

\begin{tabular}{|c|c|c|c|c|c|}
\hline \multicolumn{6}{|c|}{ A. March-October 1971} \\
\hline \multirow[b]{2}{*}{ Station } & \multicolumn{2}{|c|}{ Total } & \multirow[b]{2}{*}{$\mathrm{H}^{\prime \prime}$} & \multirow[b]{2}{*}{ D } & \multirow[b]{2}{*}{$\mathrm{J}$} \\
\hline & Species & Individuals & & & \\
\hline \multicolumn{6}{|l|}{ Ditch } \\
\hline 1 & 5 & 442 & 0.85 & 0.66 & 0.53 \\
\hline 3 & 6 & 399 & 1.35 & 0.84 & 0.76 \\
\hline 5 & 5 & 228 & 1.26 & 0.74 & 0.79 \\
\hline$X(1,3,5)$ & 5.3 & 356 & 1.64 & 2.01 & 0.69 \\
\hline 2 & 4 & 251 & 1.23 & 0.54 & 0.88 \\
\hline 4 & 5 & 351 & 1.05 & 0.68 & 0.65 \\
\hline 6 & 5 & 342 & 1.26 & 0.69 & 0.78 \\
\hline$X(2,4,6)$ & 4.7 & 315 & 1.18 & 0.64 & 0.77 \\
\hline$X(1-6)$ & 5.0 & 336 & 1.17 & 0.69 & 0.73 \\
\hline Creek & 4 & 824 & 0.53 & 0.45 & 0.38 \\
\hline Estuary & 6 & 132 & 1.13 & 1.02 & 0.62 \\
\hline \multicolumn{6}{|c|}{ B. March 1971-March1972 } \\
\hline & \multicolumn{2}{|c|}{ Total } & & & \\
\hline Station & Species & No. Fishes & $\mathrm{H}^{\prime \prime}$ & $\mathrm{D}$ & $\mathrm{J}$ \\
\hline 2 & 5 & 604 & 1.37 & 0.63 & 0.85 \\
\hline 4 & 6 & 1,400 & 0.97 & 0.69 & 0.54 \\
\hline 6 & 6 & 982 & 1.03 & 0.73 & 0.57 \\
\hline$X(2,4,6)$ & 5.7 & 995 & 1.12 & 0.68 & 0.65 \\
\hline Creek & 4 & 2,590 & 0.50 & 0.38 & 0.36 \\
\hline Estuary & 6 & 169 & 1.21 & 0.98 & 0.67 \\
\hline
\end{tabular}

that have been attempted for mosquito control in North Carolina (LaSalle and Knight 1974). Corman, Romain, King, and Appleby 2012, evaluated sediment dynamics and landscape structure of the ditched marshes and provided information to better support efforts to predict responses to restoration alternatives. They recommended that marsh alteration efforts to mitigate adverse impacts of marsh ditching not be conducted until there was a comprehensive pilot study on a small subset of the marsh to evaluate the response of hydrology, marsh sedimentation, and multiple ecological traits such as nekton, vegetation, birds, and mosquitoes. The studies conducted in 1971-1972 at North River Jarrett Bay should be repeated to determine how the impacts on fish habitat, vegetation and mosquito populations may have changed in the 42 years since these studies were initiated. We could find no studies in North Carolina that document the long term effects of mosquito control ditching on mosquito populations. These ditches were installed at tremendous cost to the taxpayers and it would seem prudent to determine the return on investment to the North Carolina taxpayers. Global warming may bring diseases to the salt marsh mosquito populations that may add to the serious public health problems that already exist. Global warming may also bring new insect species that have diseases that may 
impact humans and other animals. James, Prosser, Erwin and Taylor 2012 studied the responses of salt marsh ecosystems to mosquito control management practices along the Atlantic Coast of the USA and concluded: "The potential effects of open marsh water manipulation need to be carefully considered by resource planners when managing marshes for mosquito control." In order to demonstrate for the general public that sea level rise is an important issue, all the stumps in the Juncus marsh at the North River West site need to be precisely located and their locations marked on an accurate map. The dead material in the heart of the stumps needs to be dated by the carbon 14 or similar method and a map constructed of the date when the trees were alive. The sedimentation rate at each stump needs to be determined. In this way a map can be made of how the rise in sea level has killed the trees and how fast the marsh has invaded and killed the pine forest that once grew where the Juncus marsh now grows. Then one could better predict the rate at which tree populations near the coast of North Carolina will be replaced by marshes. In traveling the North Carolina coast since 1964 we have not observed a better place to make this important demonstration.

It would be important to document the more than $111 \mathrm{~mm}$ rise in sea level that has occurred at the project and would also be important to document the nutrient exchange between the estuaries and the extensive ditched and un-ditched Juncus marshes in North Carolina.

The vast expanses of Juncus marshes have a role in the removal of carbon dioxide from the atmosphere. The rate of carbon sequestration in these extensive marshes needs to be evaluated.

The Department of Entomology at NC State University study by Dr. Kenneth Knight and Richard LaSalle in 1971-72 that found that the mosquito ditching program managed by the North Carolina Board of Health was not effective for the control of mosquitoes was published in the Raleigh News and Observer in 1972. The ditching program had been costing the NC taxpayers several hundred thousand dollars per year and the general public was concerned about the cost and that the program was not providing any real benefits. The NC Dept. of Entomology also found that the ditchside habitat environment was providing excellent habitat for quantities of horseflies. The NC General Assembly subsequently terminated funding for the ditching of salt marshes for mosquito control. Some counties were also using mosquito control funds to build boat canals to private property, to provide drainage for private real estate development, and to build duck impoundments on private property. The University of North Carolina and North Carolina State University mosquito ditch research projects in 1971-72 saved the North Carolina taxpayers millions of dollars.

\section{CONCLUSIONS}

Ditched Juncus marshes are not a sterile habitat. Based on extensive tide gauge data and precision marsh elevation surveys, we have learned that they are subject to extensive flooding and are an integral part of the hydrology and ecology of the estuarine system. They harbor fish, invertebrates and plants. They change the ecology of an area, an impact that produces aquatic creektype habitat for many fishes and invertebrates. Ditching of Juncus marshes, as conducted at these marshes, does not appear to have beneficial impacts for control of mosquitoes. Application of open marsh water management (OMWM) techniques may provide opportunities for more effective control of mosquito populations near the upland fringes of Juncus marshes and nearby wetland habitats, at a slightly higher elevation, where most of the salt water mosquitoes breed in large quantities.

\section{LITERATURE CITED}

ADAMS, S. M. 1974. Structural and functional analysis of eelgrass fish communities. Ph.D. Thesis. Univ. of N.C., Chapel Hill. 137 p. (Diss. Abst. Int. 35:2706B-2707B).

CORMAN, S. S., C. T. ROMAIN, J. W. KING, AND P. G. APPLEBY. 2012. Salt marsh mosquito-control ditches: sedimentation, landscape change, and restoration implications. J. Coastal Res. 28(4):874-880. West Palm Beach (Florida), ISSN 0749-0208.

FOSTER, W. A. 1968. Studies on the distribution and growth of Juncus roemerianus in Southeastern Brunswick County, North Carolina. M.S. Thesis. Dept. of Zool., N.C. State Univ., Raleigh, NC. 72 p.

HARRINGTON, R. W., JR., AND E. S. HARRINGTON. 1961. Food selection among fishes invading a high subtropical salt marsh: from onset of flooding through the progress of a mosquito brood. Ecology 42:646-666.

HOMER, M. L. 1975. Seasonal abundance, diversity, and trophic structure of fish in a salt marsh creek affected by a coastal power plant. Pp. 55-59. An energy evaluation of the system of power plants, estuarine ecology and alternatives for management. Final report to Florida Power Corporation and Government agencies concerned with licensing. Systems Ecology Group Dept. Environ. Sci. Univ. Fla., Gainesville, FL.

JAMES, M. J., R. M. ERWIN, D. J. PROSSER, AND J. D. TAYLOR. 2012. Responses of salt marsh ecosystems to mosquito control management practices along the Atlantic coast (U.S.A.). Restoration Ecology 20(3):395-404.

KILGEN, R. H., A. H. HARRIS, AND D. KRAEMER. 1973. Standing crops of natural fish populations in brackish - water oil field pipeline canals. Nicholls State Univ., Thibodaux, La. Paper presented to the Fourth Ann. Meets. and Workshop World Mariculture Soc., Monterrey, Mexico. 15 p.

KJELSON, M. A., G. N. JOHNSON, R. L. GARNER, AND R. BELL. 1974. Estimated biomass for nekton communities and Populations in the Newport River estuary and an evaluation of nekton sampling methods. In Atlantic Estuarine Fisheries Center annual report to the Atomic Energy Commission, 1 July 1974, Beaufort, N.C. pp. 207-237.

KUENZLER, E. J., AND H. L. MARSHALL. 1973. Effects of mosquito control ditching on estuarine ecosystems. Water Resources Res. Inst. Rep. 81. 83 p. 
KJELSON, M. A., AND G. N. Johnson. 1973. Description and evaluation of a portable drop-net for sampling Nekton populations. Proc. $27^{\text {th }}$ Ann. Conf. Southeastern Association of Game and Fish commissioners. Pp. 653-662.

LASALLE, R. N., AND K. L. KNIGHT. 1973. The effects of ditching on the mosquito populations in some sections of Juncus salt marsh in Carteret County, North Carolina. Water Resources Res. Inst. Rep. 82.162 p.

LASALLE, RICHARD, N., AND K. L. KNIGHT. 1974. Effects of salt marsh impoundments on mosquito populations. Water Resources Res. Inst. Rep. 92.

MARSHALL, H. L. 1974. Irregularly flooded marsh. Pp. 150-169 in H. T. Odum, B. J. Copeland, and E. A. McMahan (eds.), Coastal Ecological Systems of the U.S., Vol. II. Conservation Foundation, Wash., D.C. in cooperation with Office of Coastal Environment, National Oceanic and Atmospheric Administration.

MARSHALL, H. L. 1976. Effects of mosquito control ditching on Juncus marshes and utilization of mosquito control ditches by estuarine fishes and invertebrates. Ph.D. Thesis. Univ. of N.C. Chapel Hill. 206 p.

N.C. COASTAL RESOURCE COMMISSION'S SCIENCE PANEL ON COASTAL HAZARDS. 2010. North Carolina Sea-level Rise Assessment Rept. 15 p.

ODUM, E. P., AND A. A. DE LE CRUZ. 1967. Particulate organic detritus in a Georgia salt marsh-estuarine System. Pp. 383-388 in G. Lauff (ed.), Estuaries. Amer. Assoc. Adv. Sci. Publ. No. 83.

PIELOU, E. C. 1969. An introduction to mathematical ecology. John Wiley and Sons Inc., NY. 286 p.
RADFORD, A. E., H. E. AHLES, AND C. R. BELL. 1964. Guide to the vascular flora of the Carolinas. Univ. of N.C. Press, Chapel Hill, NC.

ROESSLER, M. 1965. An analysis of the variability of fish populations taken by otter trawl in Biscayne Bay, Florida. Trans. Amer. Fish. Soc. 94(4):311-318.

STRICKLAND, J. D. H., AND T. R. PARSONS. 1968. A manual of sea water analyses. Bull. Fish. Bd. Of Can. Bull. 167. 311 p.

SUBRAHMANYAM, C. B., AND S. H. DRAKE. 1975. Studies on the animal communities in two North Florida salt marshes. Part I. Fish communities. Bull. Mar. Sci. 25:445-465.

TABB, D. C., B. DRUMMOND, AND N. KENNY. 1974. Coastal marshes of southern Florida as habitat for fishes and effects of changes in water supply on these habitats. Rosenstiel School of Mar. and Atmos. Sci., Univ. of Miami, Miami, Florida. Final Rep. to U.S. Dept. of Int., Bur. Sport Fish and Wildlife. Contract No. 14-16-0004-56. 63 p.

TONJES, DAVID, J. 2013. Impacts from ditching salt marshes in the mid Atlantic and northeastern United States Environmental Reviews, 2013, 21(2):116-126, 10.1139/er-2013-0003.

TURNER, W. R., AND G. N. JOHNSON. 1972. Standing crops of aquatic organisms in five South Carolina tidal streams. Pp. 179-191 in Port Royal Sound Environmental Study. S.C. Water Res. Comm.

ZERVAS, CHRIS. 2004. North Carolina bathymetry/topography sea level rise project: determination of sea level trends. NOAA Tech. Rept. NOS CO-OPS 041.

ZERVAS, CHRIS. 2009. Sea level variations of the United States, 1854-2006. NOAA Tech. Rept. NOS CO-OPS 053. 